\title{
Alteration of Inspiratory Muscle Strength is Related to Change in Deep Breathing Heart Rate Variability in Patients Submitted to Open-Heart Surgery
}

\author{
Açık Kalp Ameliyatı Geçiren Hastalarda İnspiratuar Kas Gücündeki Değişimin Derin Solunum \\ Kalp Hızı Değişkenliğindeki Değiş̧im ile İlişkisi
}

\author{
Karan PONGPANIT \\ (D) 0000-0002-6042-904X \\ Benya VISESCHOONHASILP \\ (D) 0000-0001-5154-9392 \\ Sukpattaraporn RUANGKLAI \\ (D) 0000-0002-8606-7067 \\ Thanawat PARIYATKARAPHAN \\ (1) 0000-0001-5119-9353 \\ Sasipa BURANAPUNTALUG \\ (1) 0000-0002-3894-4109
}

Kornanong YUENYONGCHAIWAT

(10) 0000-0002-2997-4904

Department of Physiotherapy Faculty of Allied Health Sciences Thammasa University, Pathum Thani, Thailand

\section{Sorumlu Yazar \\ Corresponding Author \\ Karan PONGPANIT \\ karan.p@allied.tu.ac.th}

Geliş Tarihi / Received : 12.03.2019

Kabul Tarihi / Accepted : 21.05.2019

Çevrimiçi Yayın Tarihi /

Available Online

: 27.05.2019

\begin{abstract}
Aim: Despite the reduction of respiratory muscle strength and cardiac autonomic modulation after open-heart surgery has been demonstrated, the association between changes in both variables has not been investigated. This study aimed to determine the correlation between change in inspiratory muscle strength and change in deep breathing heart rate variability in patients submitted to open-heart surgery.

Material and Methods: An observational cross-sectional study was conducted among 32 participants aged between 35 and 60 years who were undergoing coronary artery bypass graft and cardiac valve surgery. Inspiratory muscle strength was assessed by measuring maximal inspiratory pressure using a respiratory pressure meter (RPM 01, Micro Medical Ltd., United Kingdom). Deep breathing heart rate variability was collected using a Polar heart rate monitor (Polar Electro Ltd., Finland) during a slow and deep breathing control. Evaluations were performed on the day of admission and discharge.

Results: There was statistically significant reduction in maximal inspiratory pressure and deep breathing heart rate variability indices in discharge period $(\mathrm{p}<0.05)$. The difference of expiratory/inspiratory ratio and inspiratory-expiratory differences was significantly correlated with the change in maximal inspiratory pressure in both absolute $(r=-0.864, p=0.003$ and $\mathrm{r}=-0.841, \mathrm{p}=0.004$, respectively) and percentages of predicted values $(\mathrm{r}=-0.868, \mathrm{p}=0.003$ and $\mathrm{r}=-0.834, \mathrm{p}=0.005$, respectively).

Conclusion: Inspiratory muscle weakness was related to impair cardiac vagal modulation in patients who had undergone open-heart surgery. The present study could provide rehabilitation targets to improve inspiratory muscle strength and cardiac vagal tone.
\end{abstract}

Keywords: Inspiratory muscle strength; heart rate variability; open-heart surgery.

öz

Amaç: Açık kalp ameliyatı sonrası solunum kas kuvvetinde ve kardiyak otonomik modülasyonda azalma olmasına rağmen, her iki değişkendeki değişimler arasındaki ilişki araştırılmamıștır. Bu çalışmada açık kalp ameliyatı geçirmiş olan hastalarda inspiratuar kas gücündeki değişim ile derin solunum kalp hızı değişkenliğindeki değişim arasındaki korelasyonun belirlenmesi amaçland.

Gereç ve Yöntemler: Koroner arter bypass ameliyatı ve kalp kapak ameliyatı geçiren yaşları 35 ile 60 yıl arasında olan 32 katılımcı ile gözlemsel kesitsel bir çalışma yapıldı. İnspiratuar kas gücü, solunum basıncı ölçer (RPM 01, Micro Medical Ltd., Birleşik Krallık) kullanılarak maksimum inspiratuar basıncın ölçülmesiyle değerlendirildi. Derin solunum kalp hızı değişkenliği, yavaş ve derin solunum kontrolü sırasında Polar kalp atım hızı monitörü (Polar Electro Ltd., Finlandiya) kullanılarak ölçüldü. Değerlendirmeler kabul ve taburcu günü yapıldı. Bulgular: Taburculuk döneminde maksimum inspiratuar basınç ve derin solunum kalp hızı değişkenliği endekslerinde istatistiksel olarak anlamlı şekilde bir azalma vardı $(p<0,05)$. Ekspirasyon/inspirasyon oranı fark1 ve inspiratuar-ekspiratuar farkları ile maksimum inspiratuar basınçtaki hem mutlak (sırasıyla $r=-0,864 ; p=0,003$ ve $r=-0,841 ; p=0,004$ ) hem de öngörülen değerlerin yüzdelerinin (sırasıyla $r=-0,868 ; p=0,003$ ve $r=-0,834 ; p=0,005$ ) değişimi arasında istatistiksel olarak anlamlı bir korelasyon vard1.

Sonuç: İnspiratuar kas güçsüzlüğü, açık kalp ameliyatı geçiren hastalarda kardiyak vagal modülasyonun bozulmasına neden oldu. Bu çalışma inspiratuar kas gücünü ve kardiyak vagal tonusunu iyileştirmek için rehabilitasyon hedefleri sağlayabilir.

Anahtar kelimeler: İnspiratuar kas gücü; kalp hızı değişsenliği; açık kalp cerrahisi. 


\section{INTRODUCTION}

Postoperative pulmonary changes after open-heart surgery are caused by numerous factors involved in surgical manipulation, anesthetic agents, cardiopulmonary bypass, chest drain, thoracotomy pain, and immobilization $(1,2)$. These changes are associated with the restrictive pulmonary pattern and impaired inspiratory muscle strength (IMS) that was presented by a decrease in maximal static inspiratory pressure (MIP) postoperatively (3-5).

Heart rate variability (HRV) is a non-invasive indicator used to investigate cardiac autonomic functions. Alteration of HRV reflects the imbalance of sympathovagal tone that modulates cardiac rhythm (6). Moreover, HRV measurement with deep breathing maneuver (HRVdb) was highly accepted in clinical laboratories to measure cardiovagal modulation in a wide range of disorders (7). According to previous studies, it was shown that HRV indices were reduced in patients who had undergone coronary artery bypass graft (8) and cardiac valve surgery (9).

The respiratory cycle has synchronism with cardiac rhythm, which is known as respiratory sinus arrhythmia (RSA). The heart rate was increased during inspiration due to parasympathetic withdrawal to the sinus node and reversed it during expiration $(10,11)$. Hence, the attenuation of IMS can affect the fluctuation of cardiac vagal tone. The previous study revealed that the patients with chronic heart failure, who had inspiratory muscles weakness showed a positive correlation with the reduction of HRVdb (12).

Although the reduction of MIP and HRV after open-heart surgery have been demonstrated, the alteration of HRVdb and its association with the IMS has not been elucidated. Thus, this study aimed to investigate whether inspiratory muscle weakness would relate to the changes in cardiac autonomic functions in patients submitted to open-heart surgery.

\section{MATERIALS AND METHODS \\ Study Design and Subjects}

This study was designed as an observational, crosssectional study. Thirty-two patients, including males and females who have age within 35-60 years and were undergoing open-heart surgery that was recruited from Thammasat University Hospital, Thailand. The participants who presented chronic lung diseases, chronic heart failure, sinus rhythm disorders, myocardial infarction, unstable angina, experienced previous cardiac surgery, implanted a cardiac pacemaker, uncontrolled diabetes mellitus, uncontrolled blood pressure, neurological disorders, and used mechanical ventilator more than 24 hours after surgery were excluded.

The minimum required sample size was calculated, based on the correlation coefficient between MIP and high frequency power of HRV from the previous report by Reis et al. (12). The statistical power, level of significance, and effect size were set at 90\%, 5\%, and 0.84, respectively. This study was approved by The Human Research Ethics Committee of Thammasat University No.3 (Feb 2, 2018; 152/2560), and all participants have signed a written informed consent.

\section{Inspiratory Muscle Strength Assessment}

IMS was obtained by measuring MIP during a maximum inspiratory effort from the residual volume using respiratory pressure meter (RPM 01, Micro Medical Ltd., United Kingdom). Participants were instructed to breathe as much effort and maintained for at least one second. Three satisfactory attempts with an acceptable by no leakage of air and met the reproducible with the variation of less than $20 \%$ were used for analysis (13). The MIP values were expressed as a percentage of predicted values according to sex and age following the equations of Neder et al. (14).

Deep Breathing Heart Rate Variability Assessment

RR intervals were recorded using a V800 Polar heart rate monitor (Polar Electro Ltd., Finland) at a sampling rate of $1000 \mathrm{~Hz}$. HRVdb was recorded during deep breathing maneuver for 4 minutes in a supine position. Participants were instructed to do a deep and slow inhalation and exhalation to provide a maximal lung volume that varied from the total lung capacity to the residual volume. Each breathing cycle was performed for 10 seconds, divided into 5 seconds for inspiration and 5 seconds for expiration, which provides a maximal RSA response according to a previous report $(15,16)$. Participants controlled their respiratory cycles via a pointer clock on the computer screen and received verbal feedback from the researcher. HRVdb was analyzed in a linear method (time and frequency domains) by Kubios HRV software version 3.0.2 (Biosignal Analysis and Medical Imaging Group, University of Eastern Finland, Finland) following to the Task Force of European Society of Cardiology and the North American Society of Pacing and Electrophysiology (6).

Time domain analysis was computed from the mean of the longest RR intervals obtained during the expiratory phase divided by the mean of the shortest RR intervals obtained during the inspiratory phase (expiratory/inspiratory ratio; $\mathrm{E} / \mathrm{I})$, the difference between the mean of the highest heart rate obtained during the inspiratory phase and the mean of the lowest heart rate obtained during the expiratory phase (inspiratory-expiratory difference; $\Delta \mathrm{IE}$ ), the mean of RR intervals (MeanRR), the standard deviation of all normal RR intervals (SDNN), and the root mean square of the successive difference (RMSSD). E/I ratio and $\triangle \mathrm{IE}$ have been indicated cardiac sympathovagal balance, MeanRR and SDNN have been indicated cardiac autonomic modulation, and RMSSD has been indicated cardiac vagal modulation, subsequently. The Fast Fourier Transform (FFT) on the time series was utilized as a frequency domain. This FFT algorithm was applied to determine power spectrum density which consisted of low frequency power (LF: 0.04-0.15 Hz) and high frequency power (HF: 0.15-0.4 Hz). Spectral components were obtained in normalized units (nu). LF power has been predominantly indicated sympathetic tone, HF power has been indicated parasympathetic tone, while $\mathrm{LF} / \mathrm{HF}$ ratio has been indicated cardiac sympathovagal balance, respectively. The MIP and HRVdb indices were always evaluated in the afternoon and controlled room temperature at $25^{\circ}$ centigrade. Testing was conducted on the day of admission and discharge. In the post-operative period, all participants were received conventional physiotherapy intervention, which is followed the standard cardiac rehabilitation protocol of the hospital including breathing exercises, airway clearance techniques, early mobilization, exercise training, and ambulation training (17). 


\section{Statistical Analysis}

Shapiro-Wilk test was used to determine data distribution. Paired t-test and Pearson's correlation were used for data fitting normal distribution, while Wilcoxon sign rank test and Spearman's rank correlation were used for data not consistent with a normal distribution. Using SPSS version 23 for carrying out all of analyses and level of statistical significance was defined as $\mathrm{p}<0.05$.

\section{RESULTS}

A total of 39 participants were recruited, but seven participants were excluded because they had cardiac arrhythmias $(n=2)$, unstable angina $(n=3)$, and withdraw from the study $(n=2)$. Characteristics of the participants are shown in Table 1. Comparison of IMS and HRVdb indices between admission and discharge periods are summarized in Table 2. Post-operative absolute and percentage values of MIP ( $p=0.013$ and $p=0.005$, sequentially) and HRVdb indices including MeanRR ( $\mathrm{p}=0.009)$, SDNN ( $\mathrm{p}=0.016)$, RMSSD ( $\mathrm{p}=0.025)$, Total power $(\mathrm{p}=0.012)$, and HFnu $(\mathrm{p}=0.016)$ were significantly lower, while LFnu $(\mathrm{p}=0.016)$ was significantly higher than those evaluated preoperatively. There were no significant difference between operation periods in terms of the $\mathrm{E} / \mathrm{I}$ ratio $(\mathrm{p}=0.865), \Delta \mathrm{IE} \quad(\mathrm{p}=0.575)$, and $\mathrm{LF} / \mathrm{HF} \quad(\mathrm{p}=0.111)$. Correlation between the changes (discharge-admission) of MIP and HRVdb indices are given in Table 3. The difference of $\mathrm{E} / \mathrm{I}$ ratio and $\Delta \mathrm{IE}$ was significantly correlated with the change in MIP in both absolute ( $\mathrm{r}=-0.864$, $\mathrm{p}=0.003$ and $\mathrm{r}=-0.841, \mathrm{p}=0.004$, respectively) and $\%$ predicted values $(\mathrm{r}=-0.868, \mathrm{p}=0.003$ and $\mathrm{r}=-0.834$, $\mathrm{p}=0.005$, respectively). No significant correlation was found between the change of MIP and frequency domain of HRVdb.

\section{DISCUSSION}

The attenuation of MIP has indicated to inspiratory muscle weakness, which is shown as aforementioned that consistency of MIP was decreased after coronary artery bypass graft (3-5). The causes of these reductions may be

Table 1. Characteristics of the participants

\begin{tabular}{lc}
\hline Variables & Value \\
\hline Age (years) & $52.3 \pm 5.3$ \\
Male, n (\%) & $20(62.5)$ \\
Body mass index $\left(\mathrm{kg} / \mathrm{m}^{2}\right)$ & $24.8 \pm 4.5$ \\
Left ventricular ejection fraction (\%) & $65.3 \pm 7.5$ \\
Diagnosis, n (\%) & \\
$\quad$ Valvular heart disease & $16(50.0)$ \\
$\quad$ Coronary heart disease & $22(68.8)$ \\
Underlying disease, n (\%) & \\
$\quad$ Hypertension & $24(75.0)$ \\
$\quad$ Diabetes mellitus & $8(25.0)$ \\
$\quad$ Dyslipidemia & $18(56.3)$ \\
Spirometrics & \\
$\quad$ Forced expiratory volume in 1 second (FEV1) (\%) & $88.1 \pm 10.3$ \\
$\quad$ Forced vital capacity (FVC) (\%) & $90.0 \pm 9.5$ \\
FEV1/FVC (\%) & $96.5 \pm 9.9$ \\
Length of hospital stay (days) & $8(7-9)$ \\
\hline Values are presented as mean \pm standard deviation, median (interquartile \\
range), or number of participants (\%)
\end{tabular}

Table 2. Comparison of IMS and HRVdb indices between admission and discharge periods

\begin{tabular}{|c|c|c|c|}
\hline & Admission & Discharge & $\mathbf{p}$ \\
\hline \multicolumn{4}{|c|}{ Inspiratory muscle strength } \\
\hline $\mathrm{MIP}\left(\mathrm{cm} \mathrm{H}_{2} \mathrm{O}\right)$ & $82.0 \pm 24.6$ & $55.9 \pm 20.6$ & 0.013 \\
\hline MIP $(\%$ predicted $)$ & $82.7 \pm 30.0$ & $63.5 \pm 19.8$ & 0.005 \\
\hline \multicolumn{4}{|l|}{ Time domain } \\
\hline $\mathrm{E} / \mathrm{I}$ ratio $^{\#}$ & $1.1(1.0-1.3)$ & $1.1(1.0-1.6)$ & 0.865 \\
\hline$\Delta \mathrm{IE}(\mathrm{bpm})^{\#}$ & $8.0(1.6-20.6)$ & $7.0(2.8-34.3)$ & 0.575 \\
\hline MeanRR (ms) & $776.2 \pm 105.8$ & $640.6 \pm 34.3$ & 0.009 \\
\hline SDNN (ms) & $18.9 \pm 10.7$ & $10.7 \pm 7.1$ & 0.016 \\
\hline $\operatorname{RMSSD}(\mathrm{ms})^{\#}$ & $16.3(2.7-27.7)$ & $5.7(2.5-21.4)$ & 0.025 \\
\hline
\end{tabular}

\section{Frequency domain}

Total power $\left(\mathrm{ms}^{2}\right)^{\#} 584.7$ (121.2-1143.2) 179.5 (104.2-864.7) 0.012

$\begin{array}{lccc}\text { LFnu } & 26.1 \pm 13.3 & 53.6 \pm 23.1 & \mathbf{0 . 0 1 6} \\ \text { HFnu } & 73.9 \pm 13.3 & 46.4 \pm 23.1 & \mathbf{0 . 0 1 6} \\ \text { LF/HF } & 0.4 \pm 0.1 & 1.7 \pm 0.7 & 0.111\end{array}$

Data analyzed by Paired t-test or ${ }^{\text {\#Wilcoxon signed rank test, Values are }}$ presented as mean \pm standard deviation or median (interquartile range), IMS: inspiratory muscle strength, HRVdb: heart rate variability measurement with deep breathing maneuver, MIP: maximal inspiratory pressure, E/I ratio: expiratory/inspiratory ratio, $\Delta \mathrm{IE}$ : inspiratoryexpiratory differences, MeanRR: mean of $\mathrm{R}$ to $\mathrm{R}$ intervals for normal beats, SDNN: standard deviation of all R to R intervals, RMSSD: square root of the mean of the sum of the squares of differences between adjacent $\mathrm{R}$ to $\mathrm{R}$ intervals, LFnu: low frequency power in normalized units, HFnu: high frequency power in normalized units, LF/HF: the ratio between low and high frequency power.

Table 3. Correlation between change in MIP and change in HRVdb indices

\begin{tabular}{|c|c|c|c|c|}
\hline & \multicolumn{2}{|c|}{$\Delta \mathrm{MIP}$} & \multicolumn{2}{|c|}{$\begin{array}{c}\Delta \mathrm{MIP} \\
\text { (\% predicted) }\end{array}$} \\
\hline & $\mathbf{r}$ & $\mathbf{p}$ & $\mathbf{r}$ & $\mathbf{p}$ \\
\hline \multicolumn{5}{|l|}{ Time domain } \\
\hline$\Delta \mathrm{E} / \mathrm{I}$ ratio & -0.864 & 0.003 & -0.868 & 0.003 \\
\hline$\Delta \mathrm{IE}$ difference $(\mathrm{bpm})$ & -0.841 & 0.004 & -0.834 & 0.005 \\
\hline$\Delta$ MeanRR (ms) & 0.034 & 0.468 & 0.061 & 0.443 \\
\hline$\Delta \mathrm{SDNN}(\mathrm{ms})$ & -0.255 & 0.271 & -0.355 & 0.194 \\
\hline$\Delta \mathrm{RMSSD}(\mathrm{ms})$ & -0.169 & 0.345 & -0.146 & 0.356 \\
\hline \multicolumn{5}{|l|}{ Frequency domain } \\
\hline$\Delta$ Total power $\left(\mathrm{ms}^{2}\right)$ & -0.466 & 0.122 & -0.429 & 0.145 \\
\hline$\Delta$ LFnu & -0.294 & 0.240 & -0.263 & 0.264 \\
\hline$\Delta$ HFnu & 0.294 & 0.240 & 0.263 & 0.264 \\
\hline$\Delta \mathrm{LF} / \mathrm{HF}^{\#}$ & 0.190 & 0.326 & 0.262 & 0.265 \\
\hline
\end{tabular}

Data analyzed by Pearson's correlation or \#Spearman's rank correlation, MIP: maximal inspiratory pressure, HRVdb: heart rate variability measurement with deep breathing maneuver, $\triangle \mathrm{MIP}$ : delta change of maximal inspiratory pressure, $\Delta \mathrm{E} / \mathrm{I}$ ratio: delta change of expiratory/inspiratory ratio, $\Delta \mathrm{IE}$ differences: delta change of inspiratoryexpiratory differences, $\Delta$ meanRR: delta change of mean of $\mathrm{R}$ to $\mathrm{R}$ intervals for normal beats, $\triangle \mathrm{SDNN}$ : delta change of standard deviation of all $\mathrm{R}$ to $\mathrm{R}$ intervals, $\triangle \mathrm{RMSSD}$ : delta change of square root of the mean of the sum of the squares of differences between adjacent $\mathrm{R}$ to $\mathrm{R}$ intervals, $\triangle$ LFnu: delta change of low frequency power in normalized units, $\triangle \mathrm{HFnu}$ : delta change of high frequency power in normalized units, $\Delta \mathrm{LF} / \mathrm{HF}$ : delta change of the ratio between low and high frequency power. 
related to surgical manipulation, degree of sedation, cardioplegic agents, thermal damage, and cardiopulmonary bypass used that lead to change in pulmonary mechanics and respiratory compliance $(3,18$ 21). Also, post-operative pain may cause of immobilizing and restrictive pulmonary pattern (22). However, the pain scales in this study showed no difference between admission and discharge periods. Thus, postoperative pain may not effect on the efficacy of MIP assessments.

The alteration of cardiac autonomic function that was obtained during deep breathing maneuver was provided with the abnormal activity of cardiac vagal tone (7). In this study, the participants who had undergone open-heart surgery were showed a reduction in parasympathetic regulation, cooperating with more increased sympathetic activity on the day of discharge. Therefore, the results of this study demonstrated the resemblance to the previous research that has substantiated in coronary artery bypass graft (8) and cardiac valve surgery patients (9), even if they used the different methods of HRV measurement.

The RSA is modulated by the interaction between the respiratory and cardiovascular functions $(10,11)$. Hence, the alterations of breathing frequency and tidal volume can effect on this relation. In this study, as the respiratory rate was controlled during deep breathing manoeuver, therefore, the decrease of HRVdb values may be reflected from the reduction of tidal volume, which was possibly resulted from the decrease in inspiratory muscle strength and pulmonary compliance after surgery that was described above.

This study demonstrated the correlation between the reduction of MIP and HRVdb indices that are consistent with the previous report (12). This relation is probably occurred due to the post-operative pulmonary dysfunction that was represented by a restrictive pulmonary pattern. Assuming that inspiratory muscle weakness leads to rapid and shallow breathing with can be limited to the normal incursion of the inspiratory muscles. Thus, the firing rate of the sinus node was more inhibited in cardiac vagal tone, caused by early and extensive provoked of a pulmonary stretch receptor at peak inflation of each respiratory cycle $(23,24)$.

Although the present study had limitation slightly that is the tidal volume, as well as the end tidal of carbon dioxide, were not measured and controlled during the deep breathing protocol, we instructed the participants to breathe as deep and slow as they can also with monitored pulse oxygen saturation. Furthermore, the participants also received beta-blockers, which could generate an impact on HRV data; however, this study intended to investigate reallife situations.

\section{CONCLUSION}

This study revealed that inspiratory muscle weakness was related to impair cardiac vagal modulation in patients who had undergone open-heart surgery. This finding could provide rehabilitation targets to improve inspiratory muscle strength and restore heart rate variability.

\section{ACKNOWLEDGMENTS}

This study was supported by a research grant from Faculty of Allied Health Sciences, Thammasat University (grant number 4/2560) and Thammasat University Research
Fund under the TU Research Scholar (contract no. 2/50/2559). We would like to thank Assistant Professor Opas Sutdhabudha, Miss Chitima Kulchanarat, and Thammasat University Hospital staffs for their helped and supported. We also thank all participants who were spending their valuable time on this study.

\section{REFERENCES}

1. Weissman C. Pulmonary complications after cardiac surgery. Semin Cardiothorac Vasc Anesth. 2004;8(3):185-211.

2. Wynne R, Botti M. Postoperative pulmonary dysfunction in adults after cardiac surgery with cardiopulmonary bypass: clinical significance and implications for practice. Am J Crit Care. 2004;13(5):384-93.

3. Morsch KT, Leguisamo CP, Camargo MD, Coronel CC, Mattos W, Ortiz LD, et al. Ventilatory profile of patients undergoing CABG surgery. Rev Bras Cir Cardiovasc. 2009;24(2):180-7.

4. Barros GF, Santos Cda S, Granado FB, Costa PT, Limaco RP, Gardenghi G. Respiratory muscle training in patients submitted to coronary arterial bypass graft. Rev Bras Cir Cardiovasc. 2010;25(4):483-90.

5. Savci S, Degirmenci B, Saglam M, Arikan H, Inal-Ince D, Turan HN, et al. Short-term effects of inspiratory muscle training in coronary artery bypass graft surgery: a randomized controlled trial. Scand Cardiovasc J. 2011;45(5):286-93.

6. Heart rate variability: standards of measurement, physiological interpretation, and clinical use. Task Force of the European Society of Cardiology and the North American Society of Pacing and Electrophysiology. Circulation. 1996;93(5):1043-65.

7. Shields RW Jr. Heart rate variability with deep breathing as a clinical test of cardiovagal function. Cleve Clin J Med. 2009;76(Suppl 2):S37-40.

8. Lakusic N, Mahovic D, Kruzliak P, Cerkez Habek J, Novak M, Cerovec D. Changes in heart rate variability after coronary artery bypass grafting and clinical importance of these findings. Biomed Res Int. 2015;2015:680515.

9. Lakusic N, Slivnjak V, Baborski F, Sonicki Z. Heart rate variability in patients after cardiac valve surgery. Cent Eur J Med. 2008;3(1):65-70.

10. Hayano J, Yasuma F, Okada A, Mukai S, Fujinami T. Respiratory sinus arrhythmia. A phenomenon improving pulmonary gas exchange and circulatory efficiency. Circulation. 1996;94(4):842-7.

11. Yasuma F, Hayano J. Respiratory sinus arrhythmia: why does the heartbeat synchronize with respiratory rhythm? Chest. 2004;125(2):683-90.

12. Reis MS, Arena R, Archiza B, de Toledo CF, Catai AM, Borghi-Silva A. Deep breathing heart rate variability is associated with inspiratory muscle weakness in chronic heart failure. Physiother Res Int. 2014;19(1):16-24.

13. American Thoracic Society/European Respiratory Society. ATS/ERS Statement on respiratory muscle testing. Am J Respir Crit Care Med. 2002;166(4):518624.

14. Neder JA, Andreoni S, Lerario MC, Nery LE. Reference values for lung function tests. II. Maximal 
respiratory pressures and voluntary ventilation. Braz J Med Biol Res. 1999;32(6):719-27.

15.Song HS, Lehrer PM. The effects of specific respiratory rates on heart rate and heart rate variability. Appl Psychophysiol Biofeedback. 2003;28(1):13-23.

16. Hayano J, Mukai S, Sakakibara M, Okada A, Takata K, Fujinami T. Effects of respiratory interval on vagal modulation of heart rate. Am J Physiol. 1994;267(1 Pt 2):H33-40.

17. Cavenaghi S, Ferreira LL, Marino LH, Lamari NM. Respiratory physiotherapy in the pre and postoperative myocardial revascularization surgery. Rev Bras Cir Cardiovasc. 2011;26(3):455-61.

18. Siafakas N, Mitrouska I, Bouros D, Georgopoulos D. Surgery and the respiratory muscles. Thorax. 1999;54(5):458-65.

19. Wheeler WE, Rubis LJ, Jones CW, Harrah JD. Etiology and prevention of topical cardiac hypothermia-induced phrenic nerve injury and left lower lobe atelectasis during cardiac surgery. Chest. 1985;88(5):680-3.

20. Mazzoni M, Solinas C, Sisillo E, Bortone F, Susini G. Intraoperative phrenic nerve monitoring in cardiac surgery. Chest. 1996;109(6):1455-60.

21. Andrejaitiene J, Sirvinskas E, Bolys R. The influence of cardiopulmonary bypass on respiratory dysfunction in early postoperative period. Medicina (Kaunas). 2004;40(Suppl 1):7-12.

22. Huang AP, Sakata RK. Pain after sternotomy - review. Braz J Anesthesiol. 2016;66(4):395-401.

23. Schelegle ES. Functional morphology and physiology of slowly adapting pulmonary stretch receptors. Anat Rec A Discov Mol Cell Evol Biol. 2003;270(1):11-6.

24. Tryfon S, Kontakiotis T, Mavrofridis E, Patakas D. Hering-Breuer reflex in normal adults and in patients with chronic obstructive pulmonary disease and interstitial fibrosis. Respiration. 2001;68(2):140-4. 